\title{
PENYULUHAN TENTANG MOTIVASI DAN PENGEMBANGAN USAHA PEMULA PADA JAMAAH SANTREN AL-BADRY KARANG BARU REMPUNG LOMBOK TIMUR
}

\author{
Hailuddin $\left.{ }^{1 *}\right)$ Diswandi ${ }^{1}$, Irwan Suriadi ${ }^{1}$, Sofiati Wardah ${ }^{1}$ \\ ${ }^{1}$ Fakultas Bisnis dan Ekonomi, Universitas Mataram, Lombok Indonesia 83125 \\ ${ }^{*}$ Korespondensi: didinunram@gmail.com
}

Diterima 2 Juni 2020 / Disetujui 26 Juli 2020

\begin{abstract}
ASBTRAK
Pengelolaan dan pengembangan usaha pemula dimaksudkan untuk penggalian potensipotensi kemandirian dan pengembangan ekonomi masyarakat melalui pemberdayaan dan pengembangan ekonomi dalam pengelolaan sumber daya potensial secara berkelanjutan. Terkait dengan hal itu, penyuluhan ini bertujuan untuk memberikan motivasi, pengetahuan dan teknik dalam memulai usaha yang dijalani, baik secara individu maupun berkelompok bagi masyarakat. Dengan berlandaskan pada substansi yang dimaknai bahwa penataan dan pengembangan usaha pemula kecil berlandaskan pada ketersediaan sarana produksi lokal, pengolahan dan penataan output yang dikendalikan oleh masyarakat secara mandiri dan berkesinambungan. Subyek dari kegiatan ini adalah kelompok maupun individu para pelaku usaha dan usaha pemula Jamaah Santren Al-Badry Karang Baru Rempung Lombok Timur. Pelaksanaan kegiatan penyuluhan ini menggunakan metode diskusi, ceramah, dan ramah tamah. Hasil dari kegiatan ini adalah banyaknya hal yang diungkapkan oleh peserta dalam memulai usaha, seperti bagaimana memulai usaha, apa persiapannya, bagaimana dengan permodalan, pemasarannya kemana dan lain-lain. Karena itu tim mengajak mereka untuk membangun kemitraan usaha bersama untuk menampung permasalahan usaha yang mereka tekuni. Selanjutnya dipaparkan tentang bagaimana memulai suatu usaha dan dilanjutkan dengan penjelasan tentang pengetahuan manajemen usaha. Akhirnya harapan tim penyuluh, mereka bisa memulai usaha dengan pemahaman perencanaan usaha serta mereka termotivasi untuk mulai terjun dalam membangun suatu usaha dengan baik dan bisa berkembang.
\end{abstract}

Kata kunci: usaha pemula, usaha bersama, pemberdayaan, manajemen usaha.

\section{PENDAHULUAN}

Pembangunan jangka panjang khususnya dibidang ekonomi diupayakan untuk terus menerus dapat ditingkatkan yang sekaligus menjadi akselerator pendapatan melalui peningkatan kesempatan kerja dan berusaha (Bana, 2002). Upaya meningkatkan peluang berusaha di dalam masyarakat perlu mendapat perhatian khususnya pada kelompok usaha kecil pada lapisan masyarakat bawah.

Usaha skala kecil merupakan salah satu usaha yang dapat menciptakan lapangan kerja baru dan sebagai penunjang pembangunan ekonomi yang erat kaitannya dengan ekonomi nasional. 
Usaha ini mempunyai kedudukan, potensi dan peranan yang sangat penting dalam mewujudkan tujuan pembangunan ekonomi (Bratakusumah dan Solihin; 2004). Dimana usaha skala kecil ini mampu memperluas kesempatan kerja, distribusi pendapatan yang lebih merata dan dapat pula meningkatkan pendapatan masyarakat yang sekaligus mampu menciptakan stabilitas ekonomi.

Pembinaan dan pengembangan usaha skala kecil khususnya usaha dibidang jasa, perdagangan dan usaha kreatif lainnya telah lama mendapat perhatian pemerintah dan swasta. Bentuk perhatian diwujudkan dalam upaya pembinaan dan pengembangan seperti penyuluhan, pendidikan/pelatihan, memotivasi, konsultasi, studi banding serta dalam bentuk lainnya yang mengarah pada perbaikan mutu usaha (Mardiasmo, 2002).

Di tingkat daerah khususnya di Lombok Timur, jenis usaha skala kecil ini cukup banyak dan beraneka ragam bentuknya yang tersebar di daerah perkotaan maupun perdesaan. Cukup banyak masyarakat terlibat di dalamnya dan bahkan sebagaian besar diantaranya menjadi sumber mata pencaharian utama. Oleh karena itu, pembinaan dan penyuluhan tetap harus dilaksanakan meskipun belum merata secara keseluruhan, sebagaimana halnya yang dilakukan selama ini.

Salah satu bentuk usaha yang cukup dominan adalah usaha perdagangan khususnya dagang kecil yang merupakan jenis usaha yang mempunyai skala usaha yang sangat terbatas sumber dayanya. Meskipun memiliki kemampuan dalam menciptakan atau menyerap lapangan kerja khususnya dari kalangan keluarga sendiri. Keberadaan para pedagang kecil yang memiliki potensi besar ini khususnya yang ada di daerah pedesaan diharapkan akan mampu meningkatkan pendapatan keluarga masyarakat umumnya yang pada akhirnya akan berkontribusi secara regional maupun nasional (Halim, 2001).

Oleh karena itu, usaha-usaha pemberdayaan kelompok ini dirasa sangat penting untuk dilakukan oleh semua pihak terutama pemerintah daerah dengan penataan yang baik, pembinaan yang berkesinambungan, memperkuat aspek permodalan dan lain-lain, sehingga peran dalam penyerapan tenaga kerja dan berkontribusi dalam meningkatkan penghasilan pelaku usaha yang pada gilirannya akan meningkatkan kesejahteraan keluarga makin nyata dirasakan.

Banyak faktor yang menentukan kemampuam dalam memulai dan mengembangkan usaha skala kecil yang merupakan sektor informal ini, tetapi dalam penyuluhan dan pembinaan ini perhatian utama diarahkan pada faktorfaktor yang mendukung usaha pemula dalam pemberdayaan rumah tangga pedagang kecil dan pengembangan usaha yang sudah eksis (Kuncoro, 2004). Semua ini pada akhirnya ditujukan untuk dapat meningkatkan keterampilan dan kemampuan pelaku usaha dalam pengelolaan dan pengembangan usahanya. Karenanya diharapkan dari penyuluhan dan pembinaan ini adalah adanya peningkatan kemampuan pemberdayaan usaha, penataan lingkungan usaha yang nyaman, aman dan kemampuan serta keterampilannya dalam mengembangkan usahanya khususnya para pelaku usaha pemula dan usaha skala kecil.

\section{Kerangka Pemecahan Masalah}

Para pelaku usaha pemula seringkali menghadapi masalah/kendala terutama yang berkaitan dengan aspek keuangan atau pengelolaan modal, pemasaran dan lainnya. Permasalahan yang timbul sering terlambat diantisipasi oleh para 
pengusaha pemula yang berbentuk usaha berskala kecil. Hal demikian disebabkan terlambat mengetahui adanya permasalahan itu sehingga tanpa disadari telah berkembang menjadi problem yang kompleks. Kenyataan ini merupakan fenomena yang unik karena para pengusaha yang mempunyai sifat tradisional, tidak melihat hal itu sebagai suatu kendala. Beberapa permasalahan yang merupakan sumber dari sebab terjadinya kegagalan usaha atau sulit berkembang sebagai akibat pada pola pekerjaan yang sangat sederhana dan tradisional. Hal lain yang kurang mendukung kemajuan usaha kelompok ini adalah karena keterbatasan pengetahuan, pengalaman yang kurang serta motivasi yang masih kurang.

Kelompok sasaran dalam penyuluhan dan pembinaan ini adalah para pengusaha pemula dan pengusaha/dagang kecil yang menjadi jamaah santren Al-Badry Karang Baru Rempung Lombok Timur. Dalam penyuluhan dan pembinaan ini khalayak sasaran strategis yang dilibatkan adalah koordinator pedagang, dan pengelola santren serta para calon pengusaha/pedagang kecil setempat. Dengan kegiatan penyuluhan ini diharapkan hasilnya akan mampu diperluas kepada masyarakat lainnya yang menghadapi permasalahan yang sama.

\section{METODE KEGIATAN}

Materi yang disampaikan dalam penyuluhan dan pembinaan ini meliputi teknik memulai usaha, pengelolaan usaha, pemasaran, menejemen usaha dan kiat pengembangan usaha dan pemanfaatan waktu luang. Penyuluhan dan pembinaan ini disampaikan melalui metode ceramah, dan setelah ceramah berakhir dilanjutkan diskusi/tanya jawab dengan memberikan petunjuk atas kesulitan dan permasalahan yang dihadapi untuk dipecahkan bersama.

Kegiatan ini dilaksanakan melalui tahapan sebagai berikut.

1. Realisasi Pemecahan Masalah

Kegiatan pengabdian dan penyuluhan ini telah dilaksanakan pada hari Jumat 20 September 2019 bertempat di santren Al-Badry Karang Baru Rempung Lombok Timur. Guna membantu memecahkan permasalahan yang di hadapi oleh para peserta, maka kerangka pemecahan masalah dalam hal ini mengajak mereka agar masuk atau membangun kebersamaan/kemitraan usaha yang dapat menampung dan memecahkan permasalahan yang dihadapi. Disamping itu diberikan pengetahuan tentang tehnik memulai usaha baru, mengelola/manajemen usaha, kegiatan produksi dan lainnya. Oleh karena itu melalui penyuluhan ini diharapkan mereka mengerti dan mampu memulai usahanya, melakukan perencanaan usaha dan pengelolaan usaha, cara pembukuan sederhana, sehingga mereka termotivasi untuk berusaha dengan tekun dan dapat mengelola usahanya dengan baik, agar dapat lebih berkembang.

\section{Khalayak Sasaran Antara yang strategis} Kelompok sasaran dalam penyuluhan dan pembinaan ini adalah para pengusaha pemula, pelaku usaha existing (pemilik usaha) yang merupakan jamaah santren Al-Badry Karang Baru Rempung Lombok Timur. Dalam penyuluhan dan pembinaan ini khalayak sasaran yang strategis sering dilibatkan dalam kegiatan ini adalah pengelola Santren, Kader karang taruna (remaja) serta ibu rumah tangga peminat usaha dan pelaku usaha. Dengan demikian hasil dari kegiatan yang dilakukan diharapkan dapat diperluas kepada masyaralat lainnya 
yang berkeinginan untuk berusaha dan menghadapi permasalahan yang sama.

\section{Metode Yang Digunakan}

Materi yang disampaikan dalam penyuluhan dan pembinaan ini meliputi teknik memulai usaha, pengelolaan usaha, pemasaran, menejemen usaha dan kiat pengembangan usaha dengan pemanfaatan waktu luang. Penyuluhan dan pembinaan ini disampaikan melalui metode ceramah, dan setelah ceramah berakhir dilanjutkan diskusi dengan memberikan petunjuk atas kesulitan dari permasalahan yang dihadapi untuk dipecahkan bersama. Selanjutnya dilanjutkan dengan pendampingan/ konsultasi langsung maupun melalui terlepon seluler.

\section{HASIL DAN PEMBAHASAN}

Dari kegiatan pengabdian masyarakat ini, para peserta mendapat pengetahuan yang mendasar dalam hal bagaimana memulai suatu usaha, dan cara mengelola/manajemen usaha yang terencana, yang meliputi :

1. Tahap kegiatan memulai suatu usaha; bagaimana menentukan pilihan suatu bidang usaha, serta persiapan awal yang perlu dilakukan.

2. Pengelolaan usaha barang hasil perdagangan: bagaimana cara mengelola usahanya sehingga tujuan itu sendiri dapat tercapai yaitu untuk meningkatkan kesejahteraan para pedagang pada khususnya dan masyarakat pada umumnya.

3. Manfaat dan pentingnya kemitraan dalam usaha: Manfaat apa yang bisa diperoleh pedagang dan masyarakat umum dengan adanya jalinan usaha serta menjelaskan pentingnya kerjasama atau bermitra, bagi kesejahteraan pelaku usaha khususnya dan masyarakat pada umumnya.
4. Mengelola/Manajemen

usaha, terutama masalah pembukuan usaha, prinsip dan penyuluhan keuangan dan pengelolaan modal.

Metode dan isi materi yang disampaikan disamping mendapat sambutan baik dari para peserta penyuluhan, juga mencerminkan kebutuhan mereka dalam beraktifitas untuk meningkatkan diri dalam melaksanakan kegiatan untuk memulai suatu usaha atau yang sedang ditekuninya, baik sebagai produsen maupun sebagi pedagang. Semangat dan keseriusan Tim Penyuluh dalam melaksanakan kegiatan ini juga merupakan modal utama (sebagai faktor pendorong) untuk bergerak memulai usaha dan mengatasi keterbatasan pengetahuan dan ketrampilan usaha, sekalipun belum sepenuhnya teratasi.

Kendala yang masih perlu perhatian adalah terbatasnya anggaran yang tersedia untuk melaksanakan kegiatan pengabdian pada masyarakat secara berkelanjutan. Hal ini menjadi salah satu faktor penghambat, sehingga tidak dapat memberi kemungkinan tambahan jadwal yang sebenarnya diperlukan. Efek lain yang ditimbulkan adalah terbatasnya jumlah peserta yang dapat mengikuti penyuluhan semacam ini. Untuk itu demi luasnya efek dari kegiatan ini, perlu ada upaya lanjutan kegiatan penyuluhan dengan jumlah peserta yang lebih besar.

\section{KESIMPULAN DAN SARAN}

\section{Kesimpulan}

Dengan selesainya kegiatan
pengabdian masyarakat ini, dapat
disimpulkan bahwa dengan membangun
kegiatan usaha bersama/kemitraan dalam
usaha, hasilnya dapat menyalurkan barang
hasil usahanya secara bersama pula. Juga
untuk saling membantu dalam
permodalan serta tukar-menukar


informasi dalam kegiatan produksi, sehingga dapat memperlancar usahanya mereka. Selain itu dengan penyuluhan ini para peserta mengetahui besarnya manfaat dan pengetahuan dalam kemitraan usaha atau berkelompok dalam menjalankan usahanya. Adanya kerja sama antar kelompok/mitra usaha dapat mengatasi permasalahan yang dihadapinya secara bersama pula. Dan secara umum para peserta masih sangat kurang pengetahuan tentang tata cara memulai usaha, perencanaan usaha, dan mengelola/manajemen usaha yang baik. Oleh karena itu, dengan adanya kegiatan penyuluhan ini cukup membantu mereka untuk menambah wawasan dan pengetahuan, sehingga lebih mampu memacu mereka dalam menekuni suatu bidang usaha.

\section{Saran}

Mengingat jumlah jamaah santren Al-Badry Karang Baru Rempung Lombok Timur cukup banyak, sementara yang mendapat kesempatan mengikuti penyuluhan terbatas, maka perlu ada upaya tindak lanjut penyuluhan dengan jumlah peserta dan waktu penyuluhan yang lebih banyak untuk memberikan hasil yang lebih maksimal. Di samping itu pendampingan dari tim penyuluh diharapkan dapat berkesinambungan untuk melakukan pembinaan. Dengan demikian, kelompok ini dapat terus dibina dan dikembangkan lebih luas.

\section{DAFTAR PUSTAKA}

Bana, M, Yahya, 2002, Analisis Sistem Pengelolaan Keuangan daerah Kabupaten Alor Propinsi Nusa Tenggara Timur, Fakultas Ekonomi, UGM, Yogyakarta.

Bratakusumah, DS dan Solihin Dadang, 2004, Otonomi Penyelenggraan
Pemerintahan Daerah, PT Gramedia, Jakarta.

Halim, Abdul, 2001, Manajemen Keuangan Daerah, UPP AMP YKPN, Yogyakarta.

Kuncoro, Mudrajad, 2004, Otonomi \& Pembangunan Daerah Reformasi, Perencanaan, Strategi dan Peluang, Penerbit Erlangga, Jakarta.

Labni, 2005, Analisis Perbandingan Pemeringkatan Kemampuan Keuangan Daerah pada Pemerintah Daerah Se-Pulau Sumbawa, Mataram.

Mardiasmo, 2002, Otonomi dan Manajemen Keuangan Daerah, Andi Offset, Yogyakarta.

Robinson B. Richard dan Pearce A. John, 1997, Manajemen Strategik; Formulasi, Implementasi dan Pengendalian Jilid I, Binarupa Aksara, Jakarta.

Sumardi. 1986. Pembangunan dan Kemiskinan. Bulan Bintang. Rajawali Jakarta.

Suseno Triyanto, WHg. 1990. Pembangunan Ekonomi. Kanisius. Yogyakarta. 